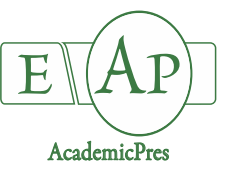

Anwar A et al. (2020)

Notulae Botanicae Horti Agrobotanici Cluj-Napoca 48(1):116-127

DOI:10.15835/nbha48111806

Research Article

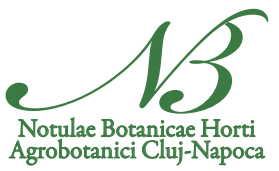

\title{
Seed priming as a promising technique to improve growth, chlorophyll, photosynthesis and nutrient contents in cucumber seedlings
}

\author{
Ali ANWAR ${ }^{1,2}$, Xianchang YU ${ }^{1}$, Yansu LI ${ }^{1 *}$ \\ ${ }^{1}$ Chinese Academy of Agricultural Sciences, Institute of Vegetables and Flowers, Beijing 100081, \\ China; liyansu@caas.cn (*correspondingauthor) \\ ${ }^{2}$ Graduate School of International Agricultural Technology and Crop Biotechnology Institute/Green Bio Science \& Technology, Seoul \\ National University, Pyeongchang, 25354, Korea; dr.ali_ivf@yahoo.com
}

\begin{abstract}
Seed priming is a technique to improve seed germination, seedlings growth, uniformity and yield. The present study was designed to, investigate the physiological mechanism of seed priming with $\mathrm{GA}_{3}$ and $\mathrm{KNO}_{3}$ on cucumber seedlings growth, chlorophyll, photosynthesis and nutrients uptake. The cucumber seeds were treated as; $\mathrm{CK}$; control, T1; $\mathrm{GA}_{3} 100 \mathrm{ppm}, \mathrm{T}_{2} ; \mathrm{GA}_{3} 200 \mathrm{ppm}, \mathrm{T}_{3} ; \mathrm{KNO}_{3} 1 \%, \mathrm{~T}_{4} ; \mathrm{KNO}_{3} 5 \%$, before seed sowing. The results showed that seed priming with $\mathrm{GA}_{3}$ and $\mathrm{KNO}_{3}$ significantly increased the plant height, fresh and dry weight and strong seedling index. Moreover, chlorophyll a, chlorophyll $b$, chlorophyll $a+b$, carotenoid contents, net photosynthesis rate (Pn), stomatal conductance (Gs), transpiration rate ( $\mathrm{Tr}$ ) and intercellular $\mathrm{CO}_{2}$ concentration in seed priming seedlings. In addition, seed priming significantly enhanced leaf macro and micro nutrient contents. Additionally, among various treatments $\mathrm{GA}_{3} 200 \mathrm{ppm}$ and $\mathrm{KNO}_{3} 5 \%$ are found best. These results suggested that seed priming with $\mathrm{GA}_{3}$ and $\mathrm{KNO}_{3}$ synergistically promoted the chlorophyll contents, photosynthesis and nutrients uptake in cucumber seedlings, thus leading to improve plant growth.
\end{abstract}

Keywords: Cucumis sativus $\mathrm{L}$; gibberellic acid; $\mathrm{KNO}_{3}$; nutrients uptake; plant growth

\section{Introduction}

Seed priming is pre-sowing treatment that can improves seed germination performance and abiotic stress tolerance. The earlier studies showed that seed priming techniques are used for improvements of seed germination under normal and adverse environmental conditions (Jisha et al., 2013) and useful physiological approaches that could adapt glycophyte species to saline conditions (Eskandari, 2013; Gholami et al., 2015; Ruttanaruangboworn $e t$ al., 2017). The positive effects of seed priming have been reported in many vegetable crops, such as tomato and pepper (Khan et al., 2009; Muhammad et al., 2010; Nakaune et al., 2012). Seed priming also stimulates metabolic processes in pre-germinated seeds and makes active seed for radical protrusion and reduce physical resistance during imbibition of endosperm, repairs membranes and also improve developments of immature embryos (Khan et al., 2009; Gamboa-Debuen et al., 2010; Kubala et al., 2015). Seed priming regulates various molecular, biochemical and physiological activities in seedlings (Yasutaka 
et al., 2005; Nakaune et al., 2012), including cell division, elongation and stress response proteins activation (Sivritepe et al., 2003; Varier et al., 2010; Mahajan et al., 2011). Thus, it can be concluded that seed priming plays a key role in plant growth and developments.

Gibberellic acid (GA) is plant hormone that produces in root of plant and play essential role in plant growth and developments (Bai et al., 2016). GA3 play a significant role in regulation of plant growth and development at different environmental conditions (Muhammad and Eui Shik, 2007; Levent et al., 2008). GA 3 is involved in improved seed germination, root growth, stem elongation and water and nutrient uptake. $\mathrm{GA}_{3}$ pre sowing seed treatments are most effective for seedlings growth and nutrients uptake (Levent $e t$ al., 2008; Bai et al., 2016). Priming of $\mathrm{GA}_{3}$ also stimulate seedlings sprouting, increase growth, activate enzymes (Muhammad and Eui Shik, 2007), that's are essential for carbohydrate metabolism, chlorophylls biosynthesis and other important enzymes, thus improve embryo developments, germination and seedlings growth, as previously reported by Varier et al. (2010). These findings are suggested that $\mathrm{GA}_{3}$ is an important plant hormone that activates variety of developmental process during plan growth.

Nitrogen $(\mathrm{N})$, potassium $(\mathrm{K})$ and phosphorous $(\mathrm{P})$ are major and essential nutrients for plant growth and development. The availability of these essential nutrients and uptakes are very important that effects growth. Plant possess a comprehensive transport system that is involved in uptake and transportation in nitrate, phosphate and potassium ion for soil though roots to shoots (Yi - Fang et al., 2008). Moreover, these nutrients, nitrogen $\left(\mathrm{KNO}_{3}\right)$ plays an important function in balancing membrane potential and activating enzymes, and regulating osmotic pressure in cells (Chérel, 2004; de Jong et al., 2014; O'Brien et al., 2016), cell wall structure, cell elongation and cell division (Patade $e t$ al., 2009). $\mathrm{KNO}_{3}$ regulate uptake of nutrients across cell membranes and enhancing water uptake (Summart et al., 2010). $\mathrm{KNO}_{3}$ or $\mathrm{CaCl}_{2}$ seed priming increased proteins, free amino acids and soluble sugars during germination under salt and water stress condition (Khan et al., 2009). Acid phosphatase and phytase enzyme activities in the cotyledons, roots and shoots of lettuce under stress were increased by seed priming of $\mathrm{KNO}_{3}$ (Nasri et al., 2011).

Cucumber (Cucumis sativus. L) is important economic vegetable crop, it is originated from southern Asia, and widely cultivated in greenhouse during winter and summer seasons, as reported by Anwar $e t$ al. (2019). Because of high nutritional value, cucumber is very commonly cultivated and consumed all around the globe and mostly in China (FAO, 2017). Induced inhibition of seedlings growth caused by many environmental factors; light, temperature, and other abiotic stress, effects many physiological and biochemical process including reduction in photosynthesis, chlorophyll biosynthesis, nutrients uptake or imbalance in nutrients accumulation (Shah et al., 2012; Yan et al., 2013) and inhibition of biological carbon and nitrogen fixation (Meena et al., 2016), thus leads in significant reduction in plant growth and yield of vegetable crops. Keeping in view the given facts, the current study was designed to evaluate the effect of $\mathrm{GA}_{3}$ and $\mathrm{KNO}_{3}$ seed priming at seedlings stage in cucumber. This study will provide deep understanding for protection and healthy vegetable nursery, and will be useful for protected vegetables production.

\section{Materials and Methods}

\section{Plant material and experimental setup}

The experiment was conducted at Institute of Vegetables and Flowers, Chinese Academy of Agricultural Sciences, Beijing, China. The cucumber (Cv. 'Zhongnong 26') seeds were treated with different levels of $\mathrm{GA}_{3}$ and $\mathrm{KNO}_{3}$; Control (CK) $\mathrm{T}_{1}\left(\mathrm{GA}_{3} 100 \mathrm{ppm}\right), \mathrm{T}_{2}\left(\mathrm{GA}_{3} 200 \mathrm{ppm}\right), \mathrm{T}_{3}\left(\mathrm{KNO}_{3} 1 \%\right), \mathrm{T}_{4}\left(\mathrm{KNO}_{3} 5 \%\right)$. After $12 \mathrm{~h}$ (hours) treatment (the seeds were treated with various $\mathrm{GA}_{3}$ and $\mathrm{KNO}_{3}$ concentrations for $12 \mathrm{~h}$ ) the seeds were dried at room temperature for 2 days. The seeds were grown in pots filled with soil mixture (Peat and vermiculite with $2: 1, \mathrm{v} / \mathrm{v}$ ). The experiment was conducted in control chamber having $14 \mathrm{~h}$ photoperiod (300 
118

$\mu \mathrm{mol} . \mathrm{m}^{-2} \mathrm{~s}^{-1}$ ) at $25-28^{\circ} \mathrm{C}$ during day time and $18-20^{\circ} \mathrm{C}$ at night time for $10 \mathrm{~h}$. After 7 days of seed germination the nutrients solutions were applied at same rate according to Yamazaki nutrients formula for cucumber seedlings (Table 1) with two days' interval.

Table 1. Yamazaki nutrition solutions and their concentration $(\mathrm{mg} / \mathrm{L})$ for cucumber seedlings

\begin{tabular}{|c|c|c|}
\hline No & Name of compound & Concentration mg/L \\
\hline \multirow{3}{*}{$A$} & $\mathrm{Ca}\left(\mathrm{NO}_{3}\right)_{2}-4 \mathrm{H}_{2} \mathrm{O}$ & 35.4 \\
\cline { 2 - 3 } & $\mathrm{KNO}_{3}$ & 40.4 \\
\hline \multirow{3}{*}{$\mathrm{N}$} & $\mathrm{NH}_{4} \mathrm{H}_{2} \mathrm{PO}_{4}$ & 40.4 \\
\hline \multirow{4}{*}{$\mathrm{MgSO}-7 \mathrm{H}_{2} \mathrm{O}$} & 24.6 \\
\cline { 2 - 3 } & $\mathrm{Na}_{2} \mathrm{Fe}_{-}-\mathrm{EDTA}$ & 25.0 \\
\cline { 2 - 3 } & $\mathrm{H}_{3} \mathrm{BO}_{3}$ & 2.13 \\
\cline { 2 - 3 } & $\mathrm{MnSO}_{4}-4 \mathrm{H}_{2} \mathrm{O}$ & 2.86 \\
\cline { 2 - 3 } & $\mathrm{ZnSO}_{4}-7 \mathrm{H}_{2} \mathrm{O}$ & 0.22 \\
\cline { 2 - 3 } & $\mathrm{CuSO}_{4}-5 \mathrm{H}_{2} \mathrm{O}$ & 0.08 \\
\hline
\end{tabular}

\section{Measurement of plant growth parameters}

The same sizes of plants were selected after 15 days after seeds germination, to determined height and hypocotyl diameter using ruler and digital venire caliper respectively as described by Anwar et al. (2019). To determine fresh and dry weight, roots and shoots were separated and weighted as as described by Bai et al. (2016).

\section{Chlorophyll contents measurement}

To determine chlorophyll contents, fully expend fresh leave form each treatment $(0.2 \mathrm{~g})$ were homogenized in $95 \%$ ethanol for $24 \mathrm{~h}$. The absorbance was read $665 \mathrm{~nm}, 649 \mathrm{~nm}$ and $470 \mathrm{~nm}$, using spectrophotometer (Anwar et al., 2018). The chlorophyll was calculated by using following formula:

Chlorophyll a $(\mathrm{mg} / \mathrm{L})=12.21 \mathrm{OD} 663-2.81 \mathrm{OD} 646$

Chlorophyll b $(\mathrm{mg} / \mathrm{L})=20.13 \mathrm{OD} 646-5.03 \mathrm{OD} 663$

Carotenoid $(\mathrm{mg} / \mathrm{L})=(1000 \mathrm{OD} 470-3.27 \mathrm{Ca}-104 \mathrm{Cb}) / 229$

Chlorophyll (a, b and Carotenoid) (mg/g. FW) $=\mathrm{C}^{*} \mathrm{~V}^{*} \mathrm{n} / \mathrm{W}(\mathrm{V}=0.02 \mathrm{~L}, \mathrm{n}=1, \mathrm{~W}=0.2 \mathrm{~g})$

\section{Measurement of photosynthesis}

The net photosynthesis rate $(\mathrm{Pn})$, stomatal conductance (Gs), transpiration rate (Tr) and intercellular $\mathrm{CO}_{2}$ concentration of $3^{\text {rd }}$ fully expanded leaf was determined by using portable photosynthesis system (LI6400XT, LI-COR Lincoln, US) as described earlier (Anwar et al., 2018).

\section{Measurement of total nutrient contents}

The total nutrient contents in plant leaves were determined by element analyser (Vario MAX CN Elemental Analyzer, Elementar, Hanau, Germany). The samples were $1^{\text {st }}$ digested in $\mathrm{HNO}_{3}$ by using microwave digestion system (Mars X press Microwave Digestion system, CEM, Matthews, NC, USA). Samples were then analysed for total nutrient concentrations with an inductively coupled plasma optical emission spectrometer (ICP-OES, Optima 5300 DV, Perkin Elmer, Waltham, USA), Jaldal Method were used for total N contents (Jiahui et al., 2018). 


\section{Statistical analysis}

There were four independent biological replications for each treatment, and the whole experiment was repeated four times. The data were statistically analyzed using an analysis of variance (ANOVA), and treatments were compared using the LSD test $(P=0.05)$ using Statistix 8.1 software.

\section{Results}

\section{Effect of seed priming on cucumber seedling growth}

Plant height, root length, hypocotyl diameter, fresh weight were significantly increased by $\mathrm{GA}_{3}$ and $\mathrm{KNO}_{3}$ seed priming as compare to control (CK) (Table 2). The results indicated that maximum plant height $(13.33 \mathrm{~cm})$ was noted $\mathrm{T}_{4}$ treatments, followed significantly by $\mathrm{T}_{2}$ and $\mathrm{T}_{3}$ treatments, having plant height 12.33 $\mathrm{cm}$. Minimum plant height $(10.5 \mathrm{~cm})$ was reported in control $(\mathrm{CK})$. Moreover, $\mathrm{T}_{2}$ had positively increase hypocotyl diameter as compared to control (CK), but the difference between $T_{1}$ and $T_{3}$ were reported nonsignificant. Fresh weight was also significantly increased in $\mathrm{GA}_{3}$ and $\mathrm{KNO}_{3}$ seed priming cucumber seedlings, as compared to $\mathrm{CK}$. In this study $\mathrm{T}_{2}$ was caused of notable increment in shoot, root and total fresh weight (Table 2). In addition, fresh weight $51.80 \%$ and $44 \%$ were increased in $\mathrm{T}_{2}$ and $\mathrm{T}_{4}$ respectively, as compared to CK.

Table 2. Effect of $\mathrm{GA}_{3}$ and $\mathrm{KNO}_{3}$ seed priming on plant height, root length, hypocotyl diameter and fresh weight

\begin{tabular}{|c|c|c|c|c|c|}
\hline No & $\begin{array}{c}\text { Plant height } \\
(\mathrm{cm})\end{array}$ & $\begin{array}{c}\text { Hypocotyl dimeter } \\
(\mathrm{mm})\end{array}$ & $\begin{array}{c}\text { Shoot fresh weight } \\
(\mathrm{g})\end{array}$ & $\begin{array}{c}\text { Root fresh weight } \\
(\mathrm{g})\end{array}$ & $\begin{array}{c}\text { Total fresh weight } \\
(\mathrm{g})\end{array}$ \\
\hline CK & $10.5 \pm 0.71 \mathrm{c}$ & $1.86 \pm 0.04 \mathrm{c}$ & $10.97 \pm 1.34 \mathrm{c}$ & $2.35 \pm 0.59 \mathrm{c}$ & $13.34 \pm 1.32 \mathrm{c}$ \\
\hline T1 & $11.67 \pm 0.57 \mathrm{~b}$ & $2.14 \pm 0.06 \mathrm{~b}$ & $13.25 \pm 0.44 \mathrm{~b}$ & $2.51 \pm 0.20 \mathrm{bc}$ & $15.76 \pm 0.35 \mathrm{~b}$ \\
\hline T2 & $12.33 \pm 0.60 \mathrm{ab}$ & $2.26 \pm 0.13 \mathrm{a}$ & $17.04 \pm 1.71 \mathrm{a}$ & $3.21 \pm 0.48 \mathrm{a}$ & $20.25 \pm 1.26 \mathrm{a}$ \\
\hline T3 & $12.33 \pm 0.60 \mathrm{ab}$ & $2.19 \pm 0.09 \mathrm{ab}$ & $15.85 \pm 0.89 \mathrm{a}$ & $3.06 \pm 0.27 \mathrm{ab}$ & $18.91 \pm 1.10 \mathrm{a}$ \\
\hline T4 & $13.33 \pm 1.15 \mathrm{a}$ & $2.17 \pm 0.05 \mathrm{ab}$ & $15.98 \pm 0.72 \mathrm{a}$ & $3.23 \pm 0.11 \mathrm{a}$ & $19.21 \pm 0.64 \mathrm{a}$ \\
\hline
\end{tabular}

Data represent the mean values \pm standard deviations. Different letters indicate significant differences at $P<0.05$. CK:

Control, T1: $\mathrm{GA}_{3} 100$ ppm, T2: GA 200 ppm, T3: $\mathrm{KNO}_{3}$ 1\%, T4: $\mathrm{KNO}_{3} 5 \%$

\section{Effect of seed priming on cucumber seedling dry weight}

Seed priming with $\mathrm{GA}_{3}$ and $\mathrm{KNO}_{3}$ resulted in a significant increased dry weight of cucumber seedlings, as compared to $\mathrm{CK}$, as presented in Table 3. The results indicated that among various treatments, shoot, root and total dry weight, $\left(1.49 \mathrm{~g}, 0.24 \mathrm{~g}\right.$ and $1.73 \mathrm{~g}$ respectively) were noted in $\mathrm{T}_{4}$ treatment, whereas $1.55 \mathrm{~g}$ total dry weight was recorded in $\mathrm{T}_{3}$. Dry weight was found lowest $(1.23 \mathrm{~g})$ in control $(\mathrm{CK})$ treatment. Strong seedling index (SSI) was reported significantly higher in $\mathrm{T}_{4}$ treatments $(0.60)$, while lowest was noted in CK (0.43), but the difference between $T_{2}$ and $T_{3}$ were found non-significant. These findings are suggested that $G A_{3}$ and $\mathrm{KNO}_{3}$ seed priming play important role in cucumber seedlings growth.

Table 3. The effect of $\mathrm{GA}_{3}$ and $\mathrm{KNO} 3$ seed priming on dry weight of shoot, root, total and root/shoot ratio

\begin{tabular}{|c|c|c|c|c|}
\hline No. & Shoot dry weight $(\mathrm{g})$ & Root dry weight $(\mathrm{g})$ & Total dry weight $(\mathrm{g})$ & SSI \\
\hline $\mathrm{CK}$ & $1.04 \pm 0.03 \mathrm{c}$ & $0.18 \pm 0.01 \mathrm{~b}$ & $1.23 \pm 0.06 \mathrm{~d}$ & $0.43 \pm 0.01 \mathrm{~d}$ \\
\hline $\mathrm{T}_{1}$ & $1.20 \pm 0.07 \mathrm{~b}$ & $0.18 \pm 0.02 \mathrm{~b}$ & $1.39 \pm 0.07 \mathrm{bc}$ & $0.47 \pm 0.01 \mathrm{c}$ \\
\hline $\mathrm{T}_{2}$ & $1.27 \pm 0.01 \mathrm{~b}$ & $0.19 \pm 0.03 \mathrm{~b}$ & $1.45 \pm 0.01 \mathrm{c}$ & $0.53 \pm 0.02 \mathrm{~b}$ \\
\hline $\mathrm{T}_{3}$ & $1.32 \pm 0.07 \mathrm{~b}$ & $0.23 \pm 0.04 \mathrm{a}$ & $1.55 \pm 0.09 \mathrm{~b}$ & $0.51 \pm 0.0 .1 \mathrm{~b}$ \\
\hline $\mathrm{T}_{4}$ & $1.49 \pm 0.012 \mathrm{a}$ & $0.24 \pm 0.03 \mathrm{a}$ & $1.73 \pm 0.01 \mathrm{a}$ & $0.60 \pm 0.02 \mathrm{a}$ \\
\hline
\end{tabular}

Data represent the mean values \pm standard deviations. Different letters indicate significant differences at $P<0.05$. CK: Control, T1: GA 3100 ppm, T2: GA 200 ppm, T3: $\mathrm{KNO}_{3}$ 1\%, T4: $\mathrm{KNO}_{3} 5 \%$ 
120

\section{Effect of seed priming on cucumber seedling chlorophyll contents}

Chlorophyll is the most important parameter that play an important role in photosynthetic capacity. In present study, the chlorophylls contents were significantly enhanced by $\mathrm{GA}_{3}$ and $\mathrm{KNO}_{3}$ seed priming, as presented in Figure 1. The results indicated that total chlorophyll contents (Chlorophyll $a, b$, $a+b$ and carotenoid) were reported significantly higher in $\mathrm{T}_{4}$ having $2.19,0.89,0.49$ and $3.02 \mathrm{mg} / \mathrm{g} \mathrm{FW}$, respectively, followed by $\mathrm{T}_{2}(2.09,0.77,0.47$ and $2.86 \mathrm{mg} / \mathrm{g} \mathrm{FW})$ treatment in cucumber seedlings, but there is no significant difference between $T_{1}, T_{3}$, but significantly higher than $C K$, as presented in Figure 1. These findings are suggested the seed priming with $\mathrm{GA}_{3}$ and $\mathrm{KNO}_{3}$ significantly enhanced chlorophylls accumulation.
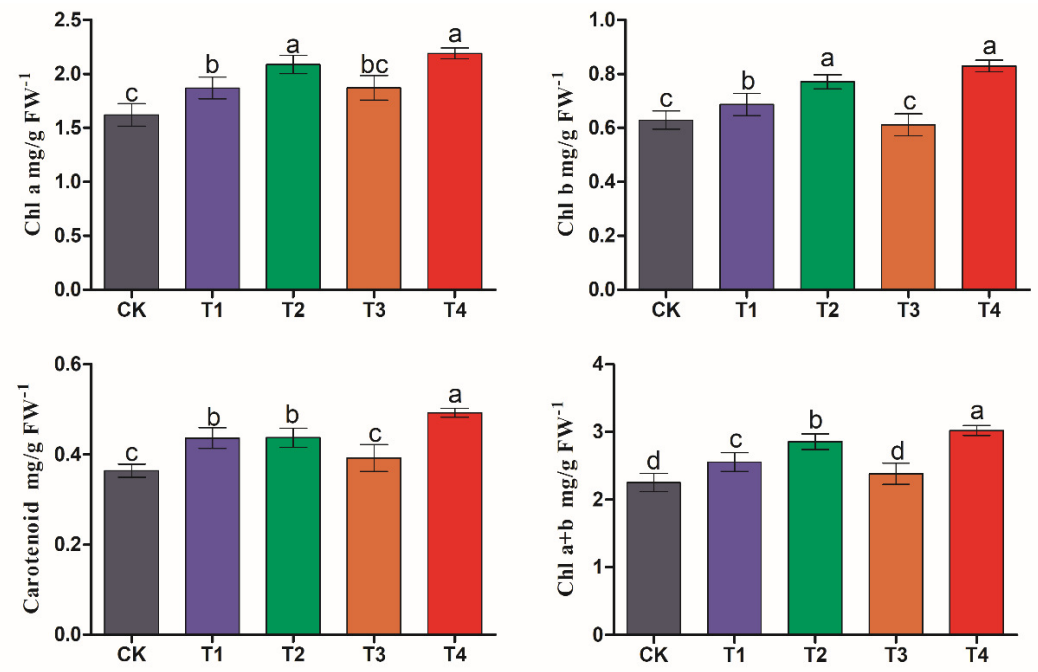

Figure 1. The effect of seed priming on chlorophyll contents in cucumber seedlings. Data represent the mean values \pm standard deviations. Different letters indicate significant differences at $P<0.05$. CK: Control, T1: $\mathrm{GA}_{3}$ 100ppm, T2: $\mathrm{GA}_{3}$ 200ppm, T3: $\mathrm{KNO}_{3}$ 1\%, T4: $\mathrm{KNO}_{3} 5 \%$

\section{Effect of seed priming on cucumber seedling photosynthesis}

As shown in Figure 2, the $\mathrm{GA}_{3}$ and $\mathrm{KNO}_{3}$ seed priming significantly improved photosynthetic parameters including net photosynthetic rate $(\mathrm{Pn})$, stomatal conductance (Gs), intercellular $\mathrm{CO}_{2}$ concentration $(\mathrm{Ci})$ and transpiration rate $(\mathrm{Tr})$ in cucumber seedlings. The results showed that $\mathrm{Pn}, \mathrm{Gs}, \mathrm{Ci}$ and Tr were increased by $55.47 \%, 88.23 \%, 51.04 \%$ and $171.82 \%$ in $\mathrm{T}_{4}$ treatment and $45.80 \%, 52.94 \%, 56.98 \%$ and 98.89\% were increased in $\mathrm{T}_{3}$, when compared to $\mathrm{CK}$. Whereas there is no significant difference between $\mathrm{T}_{1}, \mathrm{~T}_{3}$ and CK. Similarly, Gs and $\operatorname{Tr}$ were found higher in $\mathrm{T}_{1}$ and slightly decreased in $\mathrm{T}_{4}$ and $\mathrm{T}_{2}$, but remind statically higher than $\mathrm{CK}$ and $\mathrm{T}_{3}$. It can be attributed that seed priming played important role in improvements of photosynthesis by increasing chlorophyll contents (Figure 1).

\section{Effect of seed priming on total nutrients contents in cucumber leaves}

The data presented in (Table 4), shows that $\mathrm{GA}_{3}$ and $\mathrm{KNO}_{3}$ seed priming significantly $(P=0.05)$ enhanced nutrients accumulation in cucumber leaves. The results showed that nutrients accumulations were significantly higher in seed priming of $\mathrm{GA}_{3}$ and $\mathrm{KNO}_{3}$ seedlings than control treatment $(\mathrm{CK})$. 


\section{Macronutrient contents}

The contents of total nitrogen $(\mathrm{N})$ in the leaves of cucumber seedlings were significantly increased by $2.88 \%$ and $8.27 \%$ in $\mathrm{T}_{2}$ and $\mathrm{T}_{4}$ treatment respectively, as compare to CK treatment (Table 4). Moreover, $\mathrm{T}_{1}$ and $\mathrm{T}_{2}$ were also resulted in significant increment of $\mathrm{N}$ contents, when compared with $\mathrm{CK}$. Seed priming had significantly enhanced $\mathrm{P}$ contents in leaves of cucumber seedlings. $\mathrm{P}$ contents in $\mathrm{T}_{2}$ seedling leaves had increase by $6.97 \%$ and $13.95 \%$ increase were noted in $\mathrm{T}_{4}$ treatment in comparison with untreated $(\mathrm{CK})$ cucumber seedlings (Table 4). The $\mathrm{K}$ contents in cucumber leaves were significant improved by various seed priming treatments, as given in Table 4. The maximum increase $\mathrm{K} 37.9 \%$ and $35.2 \%$ reported contents were reported in $\mathrm{T}_{2}$ and $\mathrm{T}_{4}$ treatments respectively as compared CK. Mg and Ca contents were noted higher $49.7 \%$ and $40.7 \%$ in $\mathrm{T}_{2}$ and $21.55 \%$ and $42.91 \%$ in $\mathrm{T}_{1}$ respectively in leaves of cucumber seedlings, when compared with CK treatment. These findings are reflecting that seed priming played an important role in nutrient uptake and accumulation.

Table 4. Effect of seed priming on nutrients in leaves of cucumber seedling $\left(\mathrm{mg} / \mathrm{g} \mathrm{DW}^{-1}\right)$

\begin{tabular}{|c|c|c|c|c|c|}
\hline No. & $\mathrm{CK}$ & $\mathrm{T}_{1}$ & $\mathrm{~T}_{2}$ & $\mathrm{~T}_{3}$ & $\mathrm{~T}_{4}$ \\
\hline $\mathrm{N}$ & $49.65 \pm 0.18 \mathrm{c}$ & $52.34 \pm 0.42 \mathrm{ab}$ & $51.08 \pm 1.78 \mathrm{bc}$ & $52.39 \pm 1.59 \mathrm{ab}$ & $53.76 \pm 1.13 \mathrm{a}$ \\
\hline $\mathrm{K}$ & $6.16 \pm 1.04 \mathrm{~b}$ & $6.16 \pm 1.07 \mathrm{~b}$ & $8.50 \pm 0.55 \mathrm{a}$ & $8.94 \pm 0.01 \mathrm{a}$ & $8.33 \pm 1.14 \mathrm{a}$ \\
\hline $\mathrm{P}$ & $0.86 \pm 0.02 \mathrm{~b}$ & $0.92 \pm 0.00 \mathrm{ab}$ & $0.92 \pm 0.06 \mathrm{ab}$ & $0.84 \pm 0.11 \mathrm{~b}$ & $0.98 \pm 0.17 \mathrm{a}$ \\
\hline $\mathrm{Fe}$ & $0.12 \pm 0.02 \mathrm{c}$ & $0.13 \pm 0.01 \mathrm{c}$ & $0.17 \pm 0.02 \mathrm{~b}$ & $0.21 \pm 0.00 \mathrm{a}$ & $0.18 \pm 0.01 \mathrm{~b}$ \\
\hline $\mathrm{Cu}$ & $0.005 \pm 0.00 \mathrm{~b}$ & $0.005 \pm 0.00 \mathrm{~b}$ & $0.007 \pm 0.00 \mathrm{a}$ & $0.007 \pm 0.00 \mathrm{a}$ & $0.007 \pm 0.00 \mathrm{a}$ \\
\hline $\mathrm{Ca}$ & $5.15 \pm 0.65 \mathrm{~b}$ & $5.64 \pm 1.28 \mathrm{ab}$ & $7.25 \pm 2.33 \mathrm{ab}$ & $7.36 \pm 0.67 \mathrm{a}$ & $5.35 \pm 0.33 \mathrm{~b}$ \\
\hline $\mathrm{Mg}$ & $1.67 \pm 0.20 \mathrm{~b}$ & $1.70 \pm 0.21 \mathrm{~b}$ & $2.50 \pm 0.41 \mathrm{a}$ & $2.65 \pm 0.11 \mathrm{a}$ & $2.03 \pm 0.18 \mathrm{ab}$ \\
\hline $\mathrm{Ba}$ & $0.035 \pm 0.00 \mathrm{~b}$ & $0.035 \pm 0.00 \mathrm{~b}$ & $0.039 \pm 0.00 \mathrm{a}$ & $0.022 \pm 0.00 \mathrm{c}$ & $0.032 \pm 0.01 \mathrm{~b}$ \\
\hline $\mathrm{Na}$ & $0.65 \pm 0.09 \mathrm{c}$ & $0.69 \pm 0.10 \mathrm{c}$ & $1.06 \pm 0.04 \mathrm{a}$ & $0.97 \pm 0.02 \mathrm{~b}$ & $1.35 \pm 0.99 \mathrm{a}$ \\
\hline
\end{tabular}

Data represent the mean values \pm standard deviations. Different letters indicate significant differences at $P<0.05$. CK: Control, T1: $\mathrm{GA}_{3}$ 100ppm, T2: $\mathrm{GA}_{3}$ 200ppm, T3: $\mathrm{KNO}_{3} 1 \%$, T4: $\mathrm{KNO}_{3} 5 \%$

\section{Micronutrient contents}

Seed priming also enhanced micronutrient contents in leaves of cucumber seedlings, are shown in Table 4. The results indicated that seed priming increased in $\mathrm{Fe}$ and $\mathrm{Cu}$ contents by $41.6 \%$ and $40 \%$ respectively in $\mathrm{T}_{2}$ treatment, while $50 \%$, and $40 \%$ respectively, were reported in $\mathrm{T}_{4}$ treatment by comparing with $\mathrm{CK}$ treatment (Table 4). Similarly, Na contents in leaves of cucumber seedlings were also increased significantly in seed priming treatments. The Na contents were increased $63 \%$ and $107 \%$ in $\mathrm{T}_{2}$ and $\mathrm{T}_{4}$ respectively compared to CK. The $\mathrm{B}$ contents were increased in $T_{2}$, while noted lower in $T_{3}$ treatments, as shown in Table 4 . Furthermore, it can be concluded that seed priming had positively enhanced seedlings growth by enhancing nutrients uptake. Taken together, seed priming treatment $T_{2}$ and $T_{4}$ resulted a significant increment in Chlorophyll contents, photosynthetic capacity and total nutrients contents, thus enhanced cucumber seedlings growth (Table 4).

\section{Correlation analysis}

The correlation analysis indicated that chlorophylls have positive correlation with plant growth indices, while showed negative correlation with root length and root/shoot ratio dry weight (Table 5). The photosynthesis (Pn, Gs, Ci and Tr) parameters reflect a positive correlation between cucumber seedlings growth, but chlorophyll, photosynthesis showed negative correlation between root/shoot ratio. In addition, photosynthesis parameters were showed maximum positive correlation with physiological parameters, than chlorophylls, but interactive correlation between chlorophyll and photosynthesis are found positive. These 
122

results concluded that chlorophylls and photosynthesis produce changes in cucumber seedling growth, which was significantly enhanced in seed priming treatments.
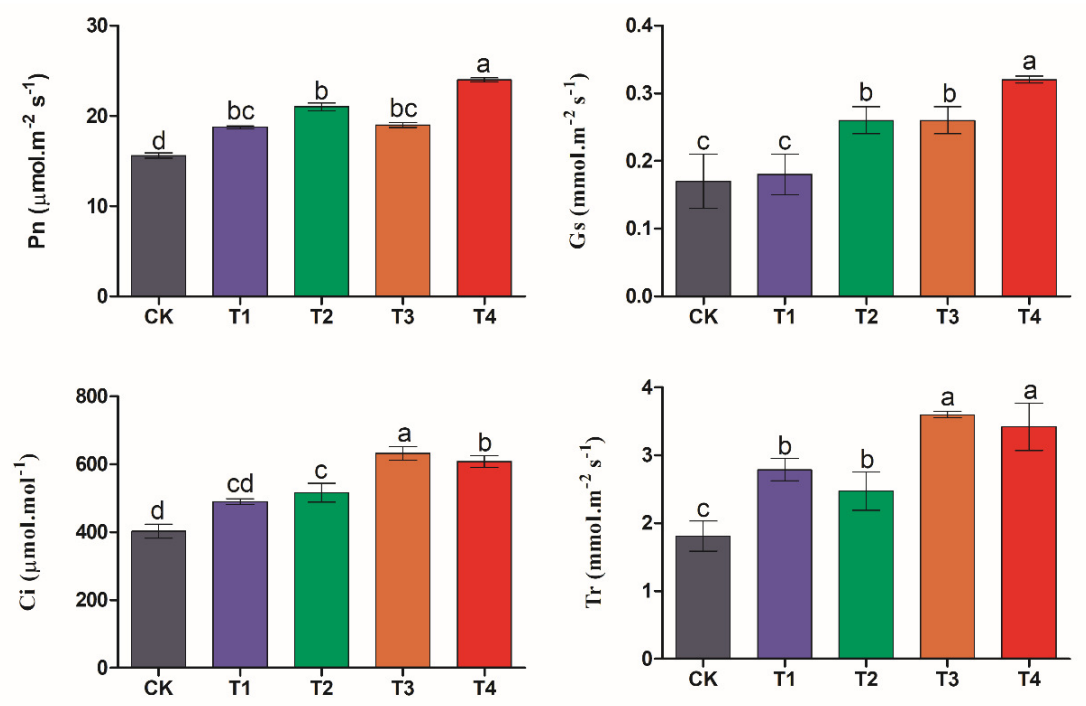

Figure 2. The effect of seed priming on photosynthesis in cucumber seedlings. Data represent the mean values \pm standard deviations. Different letters indicate significant differences at $P<0.05$. CK: Control, T1: $\mathrm{GA}_{3} 100$ ppm, T2: GA 200 ppm, T3: $\mathrm{KNO}_{3} 1 \%$, T4: $\mathrm{KNO}_{3} 5 \%$

\section{Discussion}

Seed priming techniques are recently used commercially to enhance seed vigor in term of germination and stress tolerance potential. In other words, it is also known as pre-germinative metabolism, because it activates metabolic process before seed germination, thus it showed a strong response to abiotic stress during germination. Seed priming extensively described, in term of plant ecological and physiological, cellular and molecular biology (Farooq et al., 2007; Shah et al., 2012; Sharma et al., 2014). Recently, the increased quality of seed has become a key priority of agriculture market. Seed priming is also used to achieve rapid and uniform seed germination and seedling emergence to enhanced crop production performance. In the present study, we found that seed priming increase cucumber seedlings growth; height, hypocotyl diameter, shoot, fresh weight and dry weight as compared to CK treatment (Table 2,3). The results were similar to those of earlier studies, which reported that seed priming enhanced watermelon and maize seedlings fresh weight, hypocotyl, when compared with unprimed seedlings (Demir and Mavi, 2004; Farooq et al., 2007; Imran et al., 2013). These findings are suggested that seed priming incredibly enhanced cucumber seedlings growth.

Chlorophylls are vital pigments that absorb a considerable amount of light energy and perform photosynthesis reactions in plant. Chlorophyll is very sensitive to various environmental stress, thus caused a significant reduction in chlorophyll contents and biosynthesis, thus effects plant growth and yield (Demir and Mavi, 2004; Khan et al., 2009; Shah et al., 2012). In the present study seed priming significantly increased chlorophyll contents in cucumber seedlings (Figure 1). The results are in agreement with previous studies, who reported that bio priming significantly enhanced chlorophyll contents in wheat leaves (Jiajin et al., 2010; Rahimi, 2013; Siri et al., 2013; Sharma et al., 2014). Chlorophyll contents is an important parameter often used as an indicator for developments of chloroplast and photosynthetic capacity (Xia et al., 2009; Bai et al., 
2016; Meena et al., 2016), thus considered as a base for plant growth and developmental process. In present study, seed priming also enhanced $\mathrm{N}$ and Mg contents (Table 4), which is involved in chlorophyll biosynthesis. The Chlorophyll molecule contain $\mathrm{Mg}$ covalently link with four nitrogen $(\mathrm{N})$ atoms (Chlorophyll a; $\mathrm{C}_{55} \mathrm{H}_{72} \mathrm{O}_{5} \mathrm{~N}_{4} \mathrm{Mg}$ and Chlorophyll b; $\mathrm{C}_{55} \mathrm{H}_{70} \mathrm{O}_{6} \mathrm{~N}_{4} \mathrm{Mg}$ ), so it might be the reason that seed priming enhanced nutrients uptake (Table 4) and resulted to enhanced chlorophyll contents in cucumber leaves. The correlation analysis, showed that chlorophyll have positive correlated with growth parameters and photosynthesis (Table 5). Taken together, these results suggested that seed priming enhanced chlorophyll contents thus leads to improve cucumber seedlings growth.

Table 5. Correlation analysis between plant different morphological parameters, chlorophyll and photosynthesis

Table. 5 Pearson correlation analysis between plant different morphological parameters, chlorophyll and photosynthesis

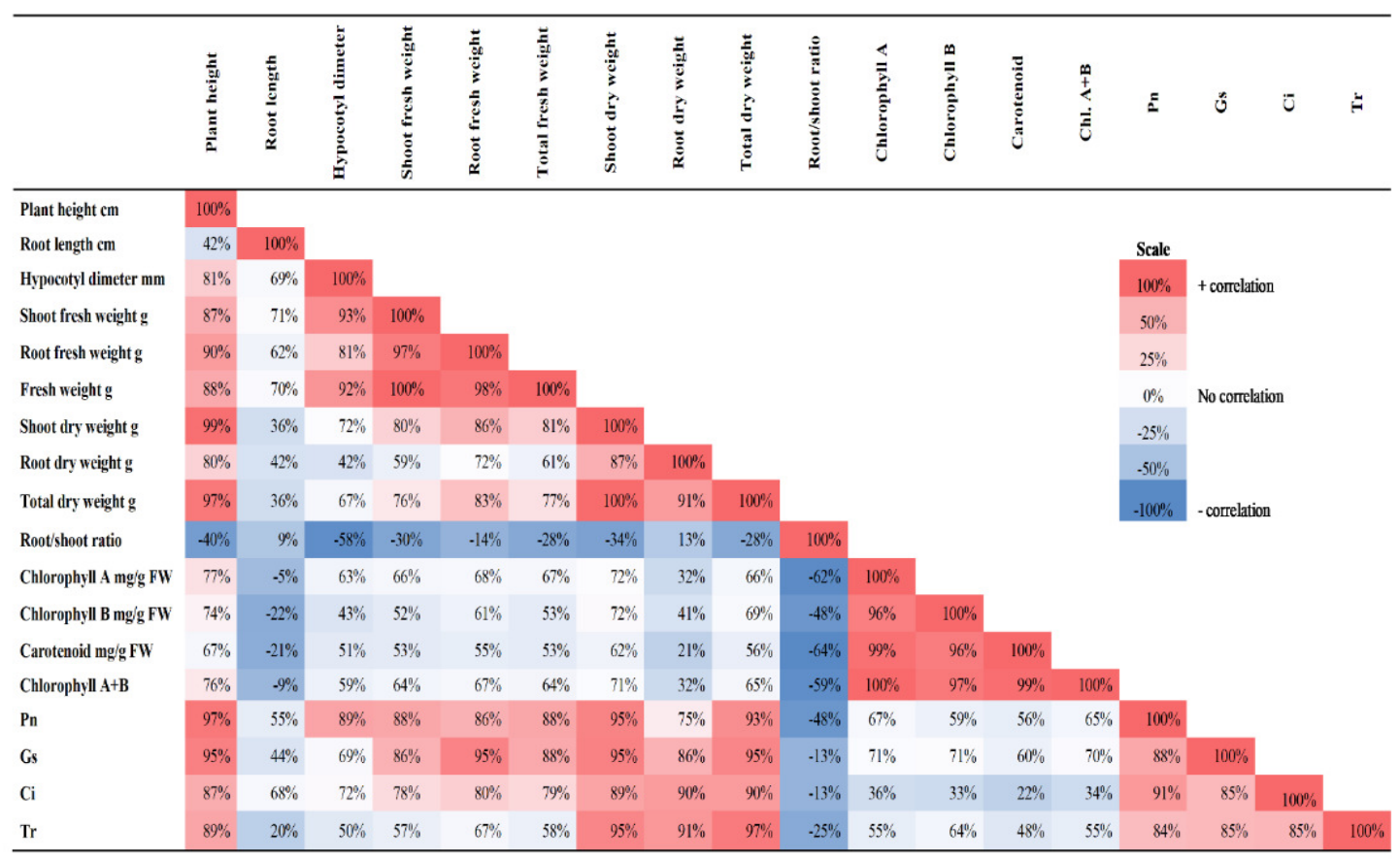

The mean data representing different plant growth effected by seed priming. Deep red color $(100 \%)$ are representing strong positive correlation and deep blue color are representing negative correlation. The negative correlation are shows non-significant correlation with other parameters.

Photosynthesis is the base of plant growth and developmental process, while its capacity is often mainly ascribed to stomatal and non-stomatal limitations, and caused of reduction in Pn capacity, as well as Gs and Ci (Shu et al., 2016). In this study, Photosynthetic activities (photosynthesis parameters including intercellular $\mathrm{CO}_{2}$ concentration $(\mathrm{Ci})$, photosynthetic rate $(\mathrm{Pn})$, stomatal conductance $(\mathrm{Gs})$ and transpiration rate $\left.(\mathrm{Tr})\right)$ were significantly improved by seed priming in cucumber seedlings, as compared to CK (Figure 2). Chlorophylls accumulation are important parameter frequently used as an indicator of photosynthetic capacity, in present study we reported that seed priming enhanced chlorophylls accumulation (Figure 1), resulted a significant increment in photosynthetic capacity (Figure 2). The previous study reported a strong correlation between leaf $\mathrm{N}$ and chlorophylls, and concluded that photosynthesis capacity is frequently attributed to chlorophyll and $\mathrm{N}$ accumulation in leaf (Castro et al., 2014), which is a key molecule for photosynthesis. In the present study, we also reported that seed priming enhanced $\mathrm{N}$ and $\mathrm{Mg}$ accumulation in cucumber leaf (Table 4). The previous study reported, that $\mathrm{N}$ and $\mathrm{Mg}$ are key molecule of chlorophyll 
124

biosynthesis, thus it might be reason that seed priming enhance leaf nutrients accumulation $(\mathrm{N}$ and $\mathrm{Mg})(\mathrm{Kut}$ ík et al., 1995; Lawlor, 2002), and ultimate enhanced chlorophylls accumulation (Figure 1), and photosynthetic capacity (Figure 2) to improve cucumber seedlings growth (Table 2). The results were similar to those of earlier studies, which reported that seed priming with Salicylic acid and PEG enhanced photosynthesis in rice seedlings (Li and Zhang, 2010; Shaheen et al., 2016), and Zhang et al. (2012), who reported that photosynthesis capacity in cucumber plant are increased by seed priming and also increased photochemical efficiency of PS II.

Sustaining ion homoeostasis by nutrients uptake and compartmentalization is not only fundamental for plant growth (Ghars et al., 2008), but also essential for almost all metabolic and cellular functions, such as energy metabolism, primary and secondary metabolism, regulation of genes, hormonal regulation, cell protection, reproduction, other signal transduction (Hansch and Mendel, 2009; Meena et al., 2016). In this study, $\mathrm{GA}_{3}$ and $\mathrm{KNO}_{3}$ seed priming resulted a significant increment in minerals nutrition concentration $(\mathrm{N}$, $\mathrm{P}, \mathrm{K}, \mathrm{Mg}, \mathrm{Ca}, \mathrm{Cu}, \mathrm{Fe}, \mathrm{Na}$ and $\mathrm{Ba}$ ) in leaves of cucumber seedlings (Table 4). The results were similar to those of earlier studies, which reported that seed priming enhanced leaf nutrients accumulation and significantly enhance seedlings growth in mungbean (Shah et al., 2012). Seed priming enhanced significantly nutrients uptake and balancing of membrane potential and regulating of osmotic pressure cells (Chérel, 2004), thus it might be reasoning that seed priming regulate nutrients uptake, chlorophylls accumulation and photosynthesis, leads significant increment in cucumber seedlings growth (Tables 1,2).

\section{Conclusions}

Taken together, we presented physiological and biochemical evidences of seed priming regulate plant growth. As expected, cucumber seedlings growth was found significantly increased $\mathrm{GA}_{3}$ and $\mathrm{KNO}_{3}$ seed priming treatments, as compared to control. The $\mathrm{KNO}_{3}$ and $\mathrm{GA}_{3}$ seed priming had improved cucumber seedlings growth, fresh and dry weight, total chlorophyll contents, photosynthetic activity and leaves nutrients contents. Moreover, the personal correlation analysis concluded that chlorophyll and photosynthesis have positive correlation with plant height, hypocotyl dimeter, fresh and dry weight, and suggested that, seed priming regulates nutrient uptake, which involved in chlorophyll biosynthesis and photosynthesis, thus regulate cucumber growth. Among the treatments $\mathrm{T}_{2}\left(\mathrm{GA}_{3} 200 \mathrm{ppm}\right)$ and $\mathrm{T}_{4}\left(\mathrm{KNO}_{3} 5 \%\right)$ seed priming was found superior and recommended for improved seedlings growth of cucumber. The finding could improve our understanding of seed priming and would be useful for healthy nursery rising and protected vegetable production.

\section{Acknowledgements}

This work was supported by National Key Research and Development Program of China (2016YFD0201006), Earmarked fund for Modern Agro-industry Technology Research System (CARS-25-C01), Science and Technology Innovation Program of Chinese Academy of Agricultural Sciences (CAASASTIP-IVFCAAS) and Key Laboratory of Horticultural Crop Biology and Germplasm Innovation, Ministry of Agriculture, China. The funders had no role in study design, data collection and analysis, decision to publish, or preparation of the manuscript.

\section{Conflict of Interests}

The authors declare that there are no conflicts of interest related to this article. 


\section{References}

Anwar A, Bai L, Miao L, Liu Y, Li S, Yu X, Li Y (2018). 24-epibrassinolide ameliorates endogenous hormone levels to enhance low-temperature stress tolerance in cucumber seedlings. International Journal of Molecular Sciences 19(9):2497.

Anwar A, $\mathrm{Li} \mathrm{Y,} \mathrm{He} \mathrm{C,} \mathrm{Yu} \mathrm{X} \mathrm{(2019).} \mathrm{24-epibrassinolide} \mathrm{promotes} \mathrm{NO}_{3}{ }^{-}$and $\mathrm{NH}_{4}{ }^{+}$ion flux rate and $\mathrm{NRT} 1$ gene expression in cucumber under suboptimal root zone temperature. BMC Plant Biology19(1):225.

Anwar A, Yan Y, Liu Y, Li Y, Yu X (2018). 5-aminolevulinic acid improves nutrient uptake and endogenous hormone accumulation, enhancing low-temperature stress tolerance in cucumbers. International Journal of Molecular Sciences 19:3379.

Bai L, Deng H, Zhang X, Yu X, Li Y (2016). Gibberellin is involved in inhibition of cucumber growth and nitrogen uptake at suboptimal root-zone temperatures. Plos One 11:e0156188.

Castro FAD, Campostrini E, Netto AT, Gomes MDMDA, Ferraz TM, Glenn DM (2014). Portable chlorophyll meter (PCM502) values are related to total chlorophyll concentration and photosynthetic capacity in papaya (Carica papaya L.). Theoretical and Experimental Plant Physiology 26:201-210.

Chérel I (2004). Regulation of $\mathrm{K}^{+}$channel activities in plants: from physiological to molecular aspects. Journal of Experimental Botany 55:337-351.

De Jong F, Thodey K, Lejay LV, Bevan MW (2014). Glucose elevates nitrate transporter 2.1 protein levels and nitrate transport activity independently of its hexokinase 1-mediated stimulation of nitrate transporter 2.1 expression. Plant Physiology 164:308-320.

Demir I, Mavi K (2004). The effect of priming on seedling emergence of differentially matured watermelon Matsum and Nakai) seeds. Scientia Horticulturae 102:467-473.

Eskandari H (2013). Effects of priming technique on seed germination properties, emergence and field performance of crops: a review. International Journal of Agronomy and Plant Production 4(3):454-458.

Farooq DM, Basra SMA, Khan MB (2007). Seed priming improves growth of nursery seedlings and yield of transplanted rice. Archives of Agronomy and Soil Science 53:315-326.

Gamboa-Debuen A, Cruz-Ortega R, Martínez-Barajas E, Sánchez-Coronado ME, Orozco-Segovia A (2010). Natural priming as an important metabolic event in the life history of Wigandia urens (Hydrophyllaceae) seeds. Physiologia Plantarum 128:520-530.

Ghars MA, Parre E, Debez A, Bordenave M, Richard L, Leport L, Bouchereau A, ... Abdelly C (2008). Comparative salt tolerance analysis between Arabidopsis thaliana and Thellungiella halophila, with special emphasis on $\left.\mathrm{K}\left({ }^{+}\right) / \mathrm{Na}^{+}\right)$ selectivity and proline accumulation. Journal of Plant Physiology 165:588-599.

Gholami M, Mokhtarian F, Baninasab B (2015). Seed halopriming improves the germination performance of black seed (Nigella sativa) under salinity stress conditions. Journal of Crop Science and Biotechnology 18:21-26.

Hansch R, Mendel RR (2009). Physiological functions of mineral micronutrients (Cu, Zn, Mn, Fe, Ni, Mo, B, Cl). Current Opinion in Plant Biology 12:259-266.

Imran M, Mahmood A, Römheld V, Neumann G (2013). Nutrient seed priming improves seedling development of maize exposed to low root zone temperatures during early growth. European Journal of Agronomy 49:141-148.

Jiahui Z, Ning Z, Congcong L, Hao Y, Meiling L, Guirui Y, ... Nianpeng H (2018). C:N:P stoichiometry in China's forests: from organs to ecosystems. Functional Ecology 32:50-60.

Jiajin Z, Weixiang W, Yun L, Wu X, Wang X (2010). Osmopriming-regulated changes of plasma membrane composition and function were inhibited by phenylarsine oxide in soybean seeds. Journal of Integrative Plant Biology 51:858-867.

Jisha KC, Vijayakumari K, Puthur JT (2013). Seed priming for abiotic stress tolerance: an overview. Acta Physiologiae Plantarum 35:1381-1396.

Khan HA, Ayub CM, Pervez MA, Bilal RM, Shahid MA, Ziaf K (2009). Effect of seed priming with NaCl on salinity tolerance of hot pepper (Capsicum annuum L.) at seedling stage. Soil and Environment 28:81-87.

Kubala S, Garnczarska M, Wojtyla Ł, Clippe A, Kosmala A, Żmieńko A, ... Quinet M (2015). Deciphering priming-induced improvement of rapeseed (Brassica napus L.) germination through an integrated transcriptomic and proteomic approach. Plant Science 231:94-113. 
126

Kutík J, Nátr L, Demmersderks HH, Lawlor DW (1995). Chloroplast ultrastructure of sugar beet (Beta vulgaris L.) cultivated in normal and elevated $\mathrm{CO}_{2}$ concentrations with two contrasted nitrogen supplies. Journal of Experimental Botany 46:1797-1802.

Lawlor D (2002). Carbon and nitrogen assimilation in relation to yield: mechanisms are the key to understanding production systems. Journal of Experimental Botany 53(370):773-787.

Li X, Zhang L (2012). SA and PEG-induced priming for water stress tolerance in rice seedling. In: Information technology and agricultural engineering. Springer, Berlin, Heidelberg pp 881-887.

Mahajan G, Sarlach RS, Japinder S, Gill MS (2011). Seed Priming effects on germination, growth and yield of dry direct-seeded rice. Journal of Crop Improvement 25:409-417.

Meena SK, Rakshit A, Meena VS (2016). Effect of seed bio-priming and N doses under varied soil type on nitrogen use efficiency (NUE) of wheat (Triticum aestivum L.) under greenhouse conditions. Biocatalysis and Agricultural Biotechnology 6:6875.

Farooq M, Basra SM, Wahid A, Ahmad N (2010). Changes in nutrient-homeostasis and reserves metabolism during rice seed priming: consequences for seedling emergence and growth. Agricultural Sciences in China 9(2):191-198.

Jamil M, Rha ES (2007). Gibberellic acid (GA3) enhance seed water uptake, germination and early seedling growth in sugar beet under salt stress. Pakistan Journal of Biological Sciences 10(4):654-658.

Nakaune M, Hanada A, Yin YG, Matsukura C, Yamaguchi S, Ezura H (2012). Molecular and physiological dissection of enhanced seed germination using short-term low-concentration salt seed priming in tomato. Plant Physiology and Biochemistry 52:28-37.

Nasri N, Kaddour R, Mahmoudi H, Olfa B, Karray-Bouraoui N, Lachaal M (2011). The effect of osmopriming on germination, seedling growth and phosphatase activities of lettuce under saline condition. African Journal of Biotechnology 10(65):14366-14372.

O'brien J, Vega A, Bouguyon E, Krouk G, Gojon A, Coruzzi G, Gutiérrez R (2016). Nitrate transport, sensing, and responses in plants. Molecular Plant 9:837-856.

Patade VY, Bhargava S, Suprasanna P (2009). Halopriming imparts tolerance to salt and PEG induced drought stress in sugarcane. Agriculture, Ecosystems and Environment 134:24-28.

Yacoubi R, Job C, Belghazi M, Chaibi W, Job D (2011). Toward characterizing seed vigor in alfalfa through proteomic analysis of germination and priming. Journal of Proteome Research 10(9):3891-3903.

Rahimi A (2013). Seed priming improves the germination performance of cumin (Cuminum syminum L.) under temperature and water stress. Industrial Crops and Products 42:454-460.

Ruttanaruangboworn A, Chanprasert W, Tobunluepop P, Onwimol D (2017). Effect of seed priming with different concentrations of potassium nitrate on the pattern of seed imbibition and germination of rice (Oryza sativa L.). Journal of Integrative Agriculture 16:605-613.

Shah H, Jalwat T, Arif M, Miraj G (2012). Seed priming improves early seedling growth and nutrient uptake in mungbean. Journal of Plant Nutrition 35:805-816.

Shaheen HL, Iqbal M, Azeem M, Shahbaz M, Shehzadi M (2016). K-priming positively modulates growth and nutrient status of salt-stressed cotton (Gossypium hirsutum) seedlings. Archives of Agronomy \& Soil Science 62:759-768.

Sharma AD, Rathore SVS, Srinivasan K, Tyagi RK (2014). Comparison of various seed priming methods for seed germination, seedling vigour and fruit yield in okra (Abelmoschus esculentus L. Moench). Scientia Horticulturae 165:75-81.

Shu S, Tang Y, Yuan Y, Sun J, Zhong M, Guo S (2016). The role of 24-epibrassinolide in the regulation of photosynthetic characteristics and nitrogen metabolism of tomato seedlings under a combined low temperature and weak light stress. Plant Physiology \& Biochemistry 107:344-353.

Siri B, Vichitphan K, Kaewnaree P, Vichitphan S, Klanrit P (2013). Improvement of quality, membrane integrity and antioxidant systems in sweet pepper (Capsicum annuum Linn.) seeds affected by osmopriming. Australian Journal of Crop Science 7(3):2068.

Sivritepe N, Sivritepe $\mathrm{HO}$, Eris A (2003). The effects of $\mathrm{NaCl}$ priming on salt tolerance in melon seedlings grown under saline conditions. Scientia Horticulturae 97:229-237.

Summart J, Thanonkeo P, Panichajakul S, Prathepha P, Mcmanus MT (2010). Effect of salt stress on growth, inorganic ion and proline accumulation in Thai aromatic rice, Khao Dawk Mali 105, callus culture. African Journal of Biotechnology 9:145-152. 
Tuna AL, Kaya C, Dikilitas M, Higgs D (2008). The combined effects of gibberellic acid and salinity on some antioxidant enzyme activities, plant growth parameters and nutritional status in maize plants. Environmental and Experimental Botany 62(1):1-9.

Varier A, Vari AK, Dadlani M (2010). The subcellular basis of seed priming. Current Science 99:450-456.

Xia XJ, Huang LF, Zhou YH, Mao WH, Shi K, Wu JX, ... Yu JQ (2009). Brassinosteroids promote photosynthesis and growth by enhancing activation of Rubisco and expression of photosynthetic genes in Cucumis sativus. Planta 230:1185.

Yan QY, Duan ZQ, Li JH, Xun L, Dong JL (2013). Cucumber growth and nitrogen uptake as affected by solution temperature and $\mathrm{NO}_{3}: \mathrm{NH}_{4}{ }^{+}$ratios during the seedling. Korean Journal of Horticultural Science \& Technology 31:393-399.

Soeda Y, Konings MC, Vorst O, van Houwelingen AM, Stoopen GM, Maliepaard CA ... van der Geest AH (2005). Gene expression programs during Brassica oleracea seed maturation, osmopriming, and germination are indicators of progression of the germination process and the stress tolerance level. Plant Physiology 137(1):354-368.

Yi - Fang C, Yi W, Wei - Hua W (2008). Membrane transporters for nitrogen, phosphate and potassium uptake in plants. Journal of Integrative Plant Biology 50:835-848.

Zhang L, Meng XX, Liu N, Yang JH, Zhang MF (2012). Effects of grafting on phosphorus uptake and utilization of watermelon at early stage under low phosphorus stress. Journal of Fruit Science 29(1):120-124.

OPEN ACCESS

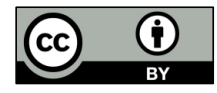

The journal offers free, immediate, and unrestricted access to peer-reviewed research and scholarly work. Users are allowed to read, download, copy, distribute, print, search, or link to the full texts of the articles, or use them for any other lawful purpose, without asking prior permission from the publisher or the author.

License - Articles published in Notulae Botanicae Horti Agrobotanici Cluj-Napoca are Open-Access, distributed under the terms and conditions of the Creative Commons Attribution (CC BY 4.0) License. (c) Articles by the authors; UASVM, Cluj-Napoca, Romania. The journal allows the author(s) to hold the copyright/to retain publishing rights without restriction. 